\title{
Rehabilitación implantosoportada en el colgajo libre de peroné
}

\section{Implant-supported rehabilitation using the fibula free flap}

\author{
C. Navarro Cuéllar' , S. Ochandiano Caicoya², F. Riba Garcia' , F.J. Lopez de Atalaya², \\ J. Acero Sanz², M. Cuesta Gil2, C. Navarro Vila
}

Resumen: El colgajo de peroné ha demostrado ser el más versatil para la reconstrucción oromandibular, gracias a la gran longitud ósea que podemos utilizar y a la posibilidad de incorporar una amplia paleta cutánea para cobertura de tejidos blandos intraorales.

El uso de implantes dentales osteointegrados proporciona un importante método terapéutico para la rehabilitación oral de estos pacientes. Los implantes osteointegrados proporcionan la forma más rígida de estabilización protésica para soportar las fuerzas masticatorias. Estos implantes pueden ser insertados de forma inmediata o diferida. A la hora de utilizar el colgajo libre de peroné realizamos la implantología de forma diferida a los 6-12 meses debido a la gran cantidad de material de osteosíntesis necesaria para la fijación del colgajo. Cuatro o seis meses después, cuando el proceso de osteointegración ha ocurrido, los implantes son cargados con una rehabilitación dental.

Analizamos 12 casos de reconstrucción mandibular con colgajo libre de peroné y su rehabilitación estética y funcional con implantes osteointegrados y un seguimiento mínimo de 2 años. Se han colocado un total de 56 implantes, presentando todos ellos excepto uno, una correcta osteointegración. Todos estos pacientes han recuperado la función masticatoria, y mejorado de forma considerable la competencia labial, la continencia salival, la pronunciación y la armonía facial.

Palabras clave: Reconstrucción mandibular; Colgajo libre de peroné; Implantes osteointegrados.

Recibido: 14.07.2003
Aceptado: 06.10.2006

\section{PREMIO “LORENZO CASTILLO"}

1 Médico Residente.

2 Médico Adjunto.

3 Jefe de Servicio. Catedrático de Cirugía Maxilofacial. Universidad Complutense de Madrid.

Servicio de Cirugía Oral yMaxilofacial.

Hospital General Universitario Gregorio Marañón. Madrid, España.

Abstract: Free fibula flap has proved to be one of the most versatile for oromandibular reconstruction due to the available length of bone and the possibility of incorporating a long skin paddle to cover intraoral soft tissues

The use of osseointegrated dental implants is an important technique for the oral rehabilitation of these patients. Osseointegrated implants provide the most rigid prosthetic stabilization available to withstand masticatory forces. These implants can be placed immediately or in a second time procedure. In our case, implantation in the fibula free flap is done after 6-12 months because of the large amount of osteosynthesis material required forthe fixation of the flap. Four or six months later, when osseointegration has taken place, the implants are loaded with a dental rehabilitation. We analize 12 cases of mandibular reconstruction with fibula free flap and their aesthetic and functional rehabilitation with osseointegrated implants with a 2 year follow up Fifty-six dental implants were placed developing all of them but one a correct osseointegration. All these patients recovered masticatory function and underwent a considerable improvement in labial competence, salival continence, speech articulation and facial harmony.

Key words: Mandibular reconstruction; Free fibula flap; Osseointegrated implants. 


\section{Introducción}

La reconstrucción mandibular dentro de la cirugía de cabeza y cuello ha sido un tema muy debatido y estudiado a lo largo de la historia y, especialmente, en los últimos 50 años. ${ }^{1}$ La extirpación de lesiones tumorales extensas da lugar, a menudo, importantes defectos óseos y de partes blandas, con sus consiguientes secuelas estéticas y funcionales. ${ }^{2}$

Desde el punto de vista estético se produce una retrusión del tercio inferior de la cara sobre todo si la mandibulectomía incluye la zona sinfisaria y parasinfisaria. En estos últimos casos se produce también una ptosis importante del labio inferior.

Cuando la resección afecta al cuerpo de la mandíbula, se produce una clara asimetría facial con hundimiento del lado afecto. Dicha asimetría es más acusada si en la resección se incluye el cóndilo.

Funcionalmente, las secuelas más importantes son: la incompetencia del labio inferior, la incontinencia salival, la dificultad severa para la masticación y deglución, y los trastornos en la articulación de la palabra.

Por un lado, la mandíbula no reconstruída tiende a la retrusión y desviación hacia el lado de la resección. Por otro, los movimientos previos verticales son reemplazados por movimientos oblicuos o diagonales controlados por una sola articulación temporomandibular. La lengua presenta limitación en cuanto a movilidad y fuerza se refiere y los trastornos de la sensibilidad propioceptiva inducen a una incoordinación de los movimientos mandibulares. ${ }^{3}$

El colgajo de peroné fue descrito inicialmente por Taylor, ${ }^{4}$ en 1975. Gilbert, en 1979, introdujo un abordaje lateral más simple, siendo el que se utiliza hoy en día. Ueba y Fukjikaua, ${ }^{5}$ comenzaron a utilizar este colgajo para el tratamiento de la pseudoartrisis congénita de cúbito en 1983. En 1988, Hidalgo, ${ }^{6}$ comienza a utilizar este colgajo para reconstrucción mandibular. Desde hace aproximadamente diez años, Navarro Vila y cols. ${ }^{7-10}$ utilizan este colgajo como una de las principales técnicas reconstructivas mandibulares.

El colgajo libre de peroné ofrece grandes ventajas para la reconstrucción mandibular. Una de las más importantes es la longitud de hueso que otorga, aportando un mínimo de $4 \mathrm{~cm}$ y un máximo de $25 \mathrm{~cm} .{ }^{11}$

El tamaño de la isla de piel a incorporar depende principalmente del tamaño de la resección y del tamaño del colgajo necesario para reconstruir el defecto oro-mandibular. La piel está irrigada por ramas septocutáneas y musculocutáneas de la arteria peronea. El estudio más importante sobre la vascularización de la piel del colgajo de peroné lo realizó Wei. ${ }^{12}$ Entre sus conclusiones destaca que el número de ramas cutáneas suele ser entre 4 y 7 , siendo los vasos musculocutáneos más numerosos a nivel proximal y las ramas septocutáneas a nivel distal. Por ello, el diseño del pedículo tiene forma fusiforme y está centrado en el septo intermuscular en la unión entre el tercio medio y distal (Fig. 1).

Por otro lado, Hayden y $\mathrm{O}^{\prime}$ Leary, ${ }^{13}$ describieron la reinervación sensitiva del parche cutáneo mediante anastómosis del nervio cutáneo sural lateral con un nervio receptor apropiado. No obstante nosotros no realizamos este procedimiento de forma rutinaria debi-

\section{Introduction}

Mandibular reconstruction, within the field of head and neck reconstruction, has been a very debated subject that has been studied over the years, and especially over the last fifty. ${ }^{1}$ The removal of extensive tumor lesions often leads to considerable bone and soft tissue defects, with the resulting aesthetic and functional sequelae. ${ }^{2}$

From the aesthetic point of view, a retraction in the lower third of the face is produced, especially if the mandibulectomy includes the symphyseal and parasymphyseal area. In these cases, considerable ptosis of the lower lip will arise.

When the resection affects the mandibular body, there is clear facial asymmetry as the affected area sinks. This asymmetry is more noticeable if, in the resection, the condyle is included.

From a functional point of view, the most important sequelae are: incompetence of the lower lip, salivary continence, severe difficulty in mastication and swallowing, and difficulty in articulation.

On the one hand the non-reconstructed part of the mandible suffers retraction and deviation towards the resection side. On the other, the previous vertical movements are replaced by oblique or diagonal movements that are controlled by just one temporomandibular joint. The tongue is limited with regard to mobility and strength and proprioceptive sensitivity disorders leads to a lack of coordination in the movements of the mandible. ${ }^{3}$

The fibula flap was first described by Taylor in 1975. Gilbert, in 1979, introduced a lateral approach that was much simpler, which is the one that is used today. Ueba and Fukjikaua started to use this flap for treating congenital cubitus pseudoarthritis in 1983. In 1988 Hidalgo ${ }^{6}$ began using this flap for reconstructing the mandible. For approximately the last ten years this is the flap used by Navarro Vila et cols.7-10 as one of the principal reconstruction techniques for the mandible.

The fibula free flap offers great advantages in mandibular reconstruction. One of the most important is the length of bone that is provided, as a minimum of $4 \mathrm{~cm}$ and a maximum of $25 \mathrm{~cm}$ is supplied. ${ }^{11}$

The size of the skin island that is to be incorporated depends principally on the size of the resection and the size of the flap that is needed for reconstructing the oromandibular defect. The skin is irrigated by septocutaneous and musculocutaneous branches of the peroneal artery. The most important study on vascularization of the skin was carried out by Weir2. One of their conclusions was that there tended to be between 4 and 7 cutaneous branches, with the more numerous musculocutaneous vessels being at a proximal level and the septocutaneous branches at a distal level. It is because of this that the pedicle has a fusiform design and it is centered in the intermuscular septum where the middle and distal third meet.

Moreover, Hayden and $\mathrm{O}^{\prime}$ Leary ${ }^{13}$ described the sensory re-innervation of a skin patch by means of anastomosis 
do a la reinervación sensitiva del colgajo sin necesidad de anastómosis nerviosa en gran número de casos.

La rehabilitación protésica dental implantosoportada ofrece a estos pacientes una solución definitiva para la recuperación de la función masticatoria y la mejoría de otras secuelas. Branemark y Lindstrom, ${ }^{14}$ utilizaron implantes en injertos óseos libres. Riediger, 15 fue el primero en colocarlos en el colgajo de cresta iliaca, Navarro Vila, ${ }^{7}$ en el colgajo osteomiocutáneo trapecial y Urken, ${ }^{16}$ el primero en colocarlos de forma inmediata en el momento de la reconstrucción.

\section{Material y método}

Para la realización de este trabajo presentamos doce pacientes sometidos a resecciones mandibulares y reconstruidos con colgajos libres de peroné, en los cuales se colocaron implantes osteointegrados de forma diferida entre 6-12 meses tras la reconstrucción (Tabla 1).

En la distribución por sexos diez fueron varones ( $88 \%$ ) y dos mujeres (12\%), con edades comprendidas entre los 21 y 73 años, con una media de 50,7 años. Dentro de nuestra serie, la causa más frecuente fueron los tumores malignos con siete de los doce casos (58\%). En otros dos pacientes la causa fue ameloblastoma mandibular, un paciente con osteorradionecrosis y un caso de secuela oncológica operado en otro centro y remitido al nuestro para su reconstrucción. Por último y en cuanto a etiología se refiere, reconstruimos un caso de agenesia hemimandibular derecha completa. En cuanto al momento de la reconstrucción de los casos oncológicos no tratados previamente, en todos ellos se realizó de forma inmediata tras la resección quirúrgica (Fig. 2).

La fijación del colgajo libre del pero-

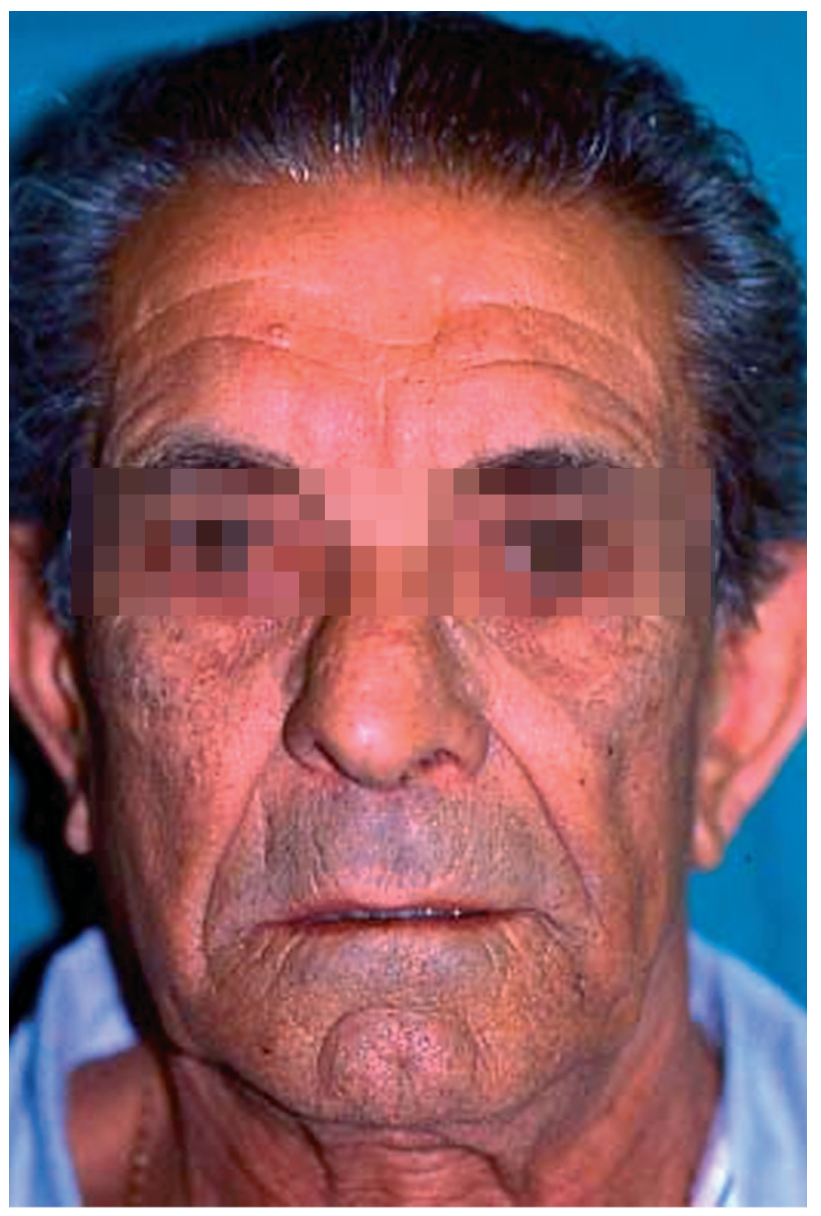

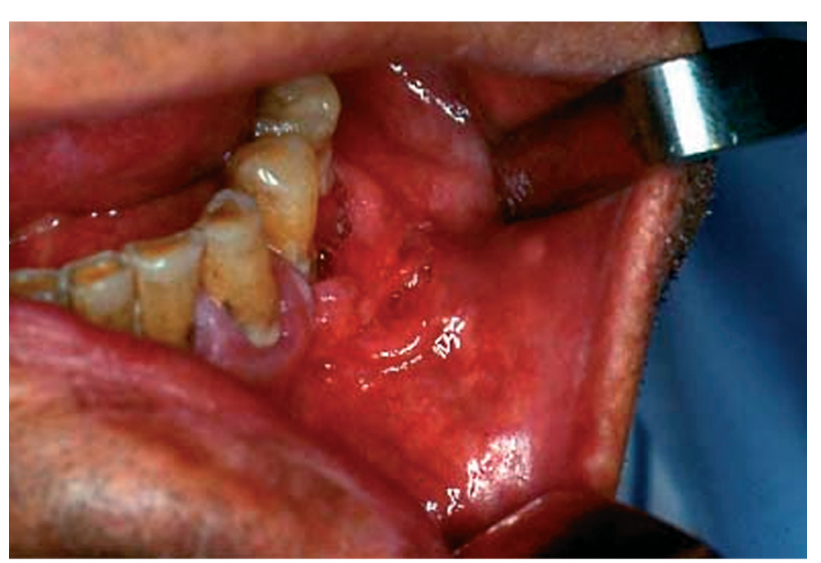

Figura 1. Paciente de 60 años diagnosticado de Ca. Epidermoide de encía mandibular a nivel del cuerpo mandibular izquierdo. Figure 1. Sixty-year old patient diagnosed with squamous cell carcinoma of the mandibular gingiva by mandibular body, left side. né a la mandíbula remanente se realizó en todos los pacientes (100\% de los casos) con miniplacas de titanio. En ningún paciente hemos realizado bloqueo intermaxilar para evitar movimientos que pudieran lesionar el pedículo vascular.

Siete de los once pacientes oncológicos (63\%) recibieron radioterapia, dos de ellos de forma preoperatoria, y cinco de ellos de forma postoperatoria. of the lateral sural cutaneous nerve with an appropriate receptor nerve. Nevertheless, we have not carried this out as a routine procedure as the sensitive reinnervation of the flap does not require anastomosis of the nerves in a large number of cases.

The implant-supported prosthetic dental rehabilitation offers these patients a definitive solution for restoring masticatory function and for improving other sequelae. Branemark y Lindstrom ${ }^{14}$ used implants with free bone grafts. Riediger ${ }^{15}$ was the first to place them in an iliac crest flap, Navarro Vila ${ }^{7}$ in the trapezius osseomyocutaneous flap and Urken ${ }^{16}$ was the first in placing them immediately, at the time of the reconstruction.

\section{Material y methods}

In this paper 12 patients are presented who underwent mandibular resection and reconstruction with the fibula free flap. They were fitted with osseointegrated implants by means of delayed placement at 6-12 months after the reconstruction (Table 1).

The sex distribution was 10 males (88\%) and two females (12\%), between the ages of 21 and 73. The mean age was 50.7 years. Within our series, the most common reason was malignant tumors in seven out of the 12 cases (58\%). In another two patients the cause was mandibular ameloblastoma, there was one patient with osteoradionecrosis and we had one case of oncological sequelae that was operated on by another center and sent to ours for reconstruction. Lastly, and as regards etiology, we reconstructed one case of complete right-sided hemimandibular agenesis. With regard to when reconstruction of the onco- 
En todos los pacientes se colocaron implantes osteointegrados de titanio recubiertos con hidroxiapatita. En todos los casos (100\%) la implantología se realizó de forma diferida entre 6 y 12 meses tras la reconstrucción mandibular. En el colgajo de peroné se colocaron un total de 56 implantes. De igual forma, en aquellos pacientes edéntulos en el maxilar superior y/o en la mandíbula remanente, también colocamos implantes en el mismo acto quirúrgico para conseguir una solución protésica dental más estable. Las dimensiones de estos implantes fueron, en la mayoría de los casos, de 10 $\mathrm{mm}$ de largo y $4 \mathrm{~mm}$ de ancho aunque hemos conseguido insertar 5 implantes de $13 \mathrm{~mm}$ y 3 de $15 \mathrm{~mm}$ en el caso de la agenesia mandibular tras una distracción ósea previa. Para su colocación inicial fue necesaria una segunda intervención en la que previamente se retiró la gran cantidad de material de osteosíntesis necesaria para la fijación del colgajo. Todos los pacientes fueron sometidos a un tratamiento antibiótico de amplio espectro durante 7-10 días. Los implantes precisaron de un periodo de osteointegración que fue de 4-6 meses para los pacientes no sometidos a radioterapia y de 6-9 meses para los pacientes radiados.

La segunda fase quirúrgica en la que se procedió al descubrimiento de los implantes se realizó mediante anestesia local excepto en un caso que precisó anestesia general debido a la limitación de la apertura oral de la paciente. Una vez sustituidos los tornillos de cierre por los pilares transmucosos de cicatrización esperamos entre 10 y 15 días para proceder a la toma de impresiones (Fig. 3).

\section{Resultados}

De los 56 implantes en colgajo peroneos, la osteointegración inicial fue del $98,2 \%$, teniendo un solo fracaso y, tras la carga protésica, con un seguimiento mínimo de dos años, el porcentaje de éxito es del $94,6 \%$ (3 implantes perdidos). La radioterapia preoperatoria no ha tenido efecto negativo estadísticamente significativo sobre los implantes. La radioterapia postoperatoria ha provocado una mínima pérdida ósea perimplantaria en 2 pacientes. No obstante la osteointegración de estos implantes fue correcta y no hubo problemas para su rehabilitación posterior. De los 12 pacientes, 8 fueron rehabilitados mediante prótesis fija implantosoportada y 4 mediante prótesis removible implantorretenida. La prótesis fija necesita un mínimo de 6 implantes, mientras que para la removible, con 3 puede ser suficiente. logical cases not treated previously took place, this was carried out in all cases immediately after surgical resection.

Titanium miniplates were used in all patients $100 \%$ of cases) for fixing the fibula free flap into the remaining mandible. In none of the patients did we carry out intermaxillary fixation in order to avoid any movements that could damage the vascular pedicle.

Seven of the 11 oncological patients (63\%) received radiotherapy, two of them preoperatively and five postoperatively.

All patients were fitted with osteointegrated titanium implants that were covered with hydroxyapatite. In all cases (100\%) the implantology was carried out as a delayed procedure between six and 12 months after the mandibular reconstruction. A total of 56 implants were placed into fibula flaps. Similarly, for those edentulous maxilla patients and/or mandible remnant patients, implants were also placed in the same surgical act in order to achieve a more stable dental prosthetic solution. The size of the implants were, in most cases, $10 \mathrm{~mm}$ in length and $4 \mathrm{~mm}$ in width although we were able to insert five implants of 13 $\mathrm{mm}$ and three of $15 \mathrm{~mm}$ in the case of mandibular agenesis after previous bone distraction. For the initial placement, a second intervention was necessary in which the large amount of osteosynthesis material that was necessary for fixing the flap was removed. All patients were given widespectrum antibiotic treatment for 7-10 days. The implants required a period of osseointegration that was 4-6 months for patients not given radiotherapy, and 6-9 months for irradiated patients.

The second surgical phase for exposing the implants was carried out using local anesthesia, except in one case that required general anesthesia due to the limited oral opening of the patient. Once the closure screws had been replaced with transmucosal healing abutments, there was a wait of 10 to 15 days before impressions were taken. 
Dentro de las complicaciones hemos registrado un cuadro de epidermolisis del colgajo y una dehiscencia de la herida intraoral, tratadas ambas satisfactoriamente con curas locales. En dos casos se había reconstruído previamente el defecto con colgajo de cresta iliaca, teniendo que ser retirado en uno de ellos por trombosis del pedículo y osteomielitis del colgajo, y en el otro por recidiva del carcinoma. Uno de los pacientes de nuestro estudio ha presentado varias complicaciones. Por un lado, necrosis parcial del músculo peroneo lateral, resuelto con tratamiento conservador al igual que una fístula orocutánea al mentón. Dicho colgajo óseo sufrió una fractura parasinfisaria derecha que precisó reintervención quirúrgica con reducción y fijación con dos miniplacas de titanio (Fig. 4).

Desde el punto de vista estético todos los pacientes están satisfechos y presentan un contorno facial correcto. Gracias a la rehabilitación protésica mediante implantes osteointegrados todos estos pacientes, excepto uno, son capaces de comer una dieta normal. Se ha recuperado la sensibilidad propioceptiva en aproximadamente la mitad de los casos y en muchos de ellos hemos conseguido una movilidad lingual aceptable. De los implantes osteointegrados hemos utilizado todos excepto cuatro, por hallarse fuera de oclusión.

Gracias a la reconstrucción mandibular y a la rehabilitación funcional con implantes osteointegrados, en todos estos pacientes hemos mejorado alguno de los problemas que afectan a la masticación, deglución, salivación, y competencia labial de forma importante, y hemos conseguido una mejoría espectacular en cuanto armonía estética facial se refiere.
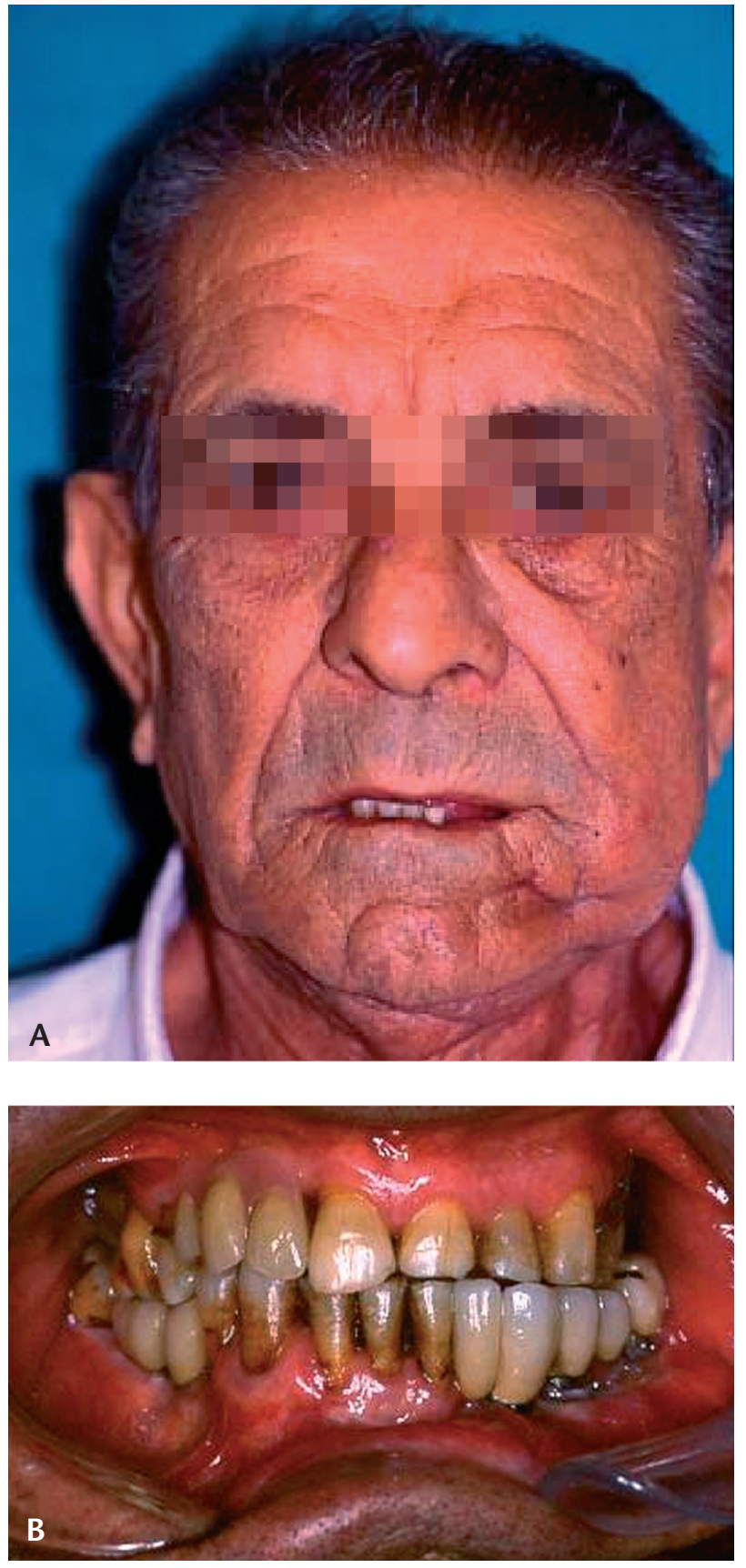

Figura 3. A) Rehabilitación protésica implantosoportada fija. B) Aspecto final del paciente.

Figure 3. A) Fixed implant-supported prosthetic rehabilitation. B) Aspecto final del paciente.

\section{Results}

Of the 56 implants that were placed into fibula flaps, initial osseointegration was 98.2\% and there was only one failure following prosthetic loading. There was a minimum two-year followup, and the success rate was 94.6\% (three lost implants). Preoperative radiotherapy did not have a negative effect on the implants that was statistically significant. Postoperative radiotherapy led to minimal peri-implant bone loss in two patients. Nevertheless, osseointegration of these implants was correct and there were no problems with later rehabilitation. Of the 12 patients, eight were fitted with implant-supported fixed prostheses, and four with removable implant-retained prostheses. The fixed prosthesis requires a minimum of six implants, while three may be sufficient for the removable one.

With regard to complications, we registered symptoms of epidermolysis of the flap and dehiscence of an intraoral wound, both responded satisfactorily with local treatment. In two of the cases the defects had been reconstructed previously with iliac crest flaps, one of which had been removed because of thrombosis of the pedicle and osteomyelitis of the flap. The other was removed because of carcinoma recurrence. One of the patients in our study had various complications that included partial necrosis of the lateral fibular muscle and an orocutaneous fistula; both were resolved with conservative treatment. The bone flap suffered a right-sided parasymphyseal fracture that required surgical reintervention and reduction and fixation with two titanium miniplates.

From the aesthetic point of view, all patients were sat-
isfied and they all had a correct facial contour. As a result of

From the aesthetic point of view, all patients were sat-
isfied and they all had a correct facial contour. As a result of tología osteointegrada se ha mejorado considerablemente el tralos últimos 20-30 años. Hasta hace poco la reconstrucción mandibular se basaba en colgajos óseos pediculados, placas de reconstrucción, injertos óseos y bandas aloplásticas con partículas de hueso. Gracias al desarrollo de las técnicas microquirúrgicas y de la implan- 
tamiento integral de los pacientes oncológicos. ${ }^{17}$

La rehabilitación oromandibular es una tarea ardua que requiere una reconstrucción compleja, individualizada para cada defecto y adaptada a las necesidades del paciente. Es fundamental individualizar cada caso y estudiar minuciosamente cada paciente para seleccionar el colgajo microquirúrgico adecuado para la reconstrucción.

El colgajo microquirúrgico de peroné aporta una serie de ventajas respecto a otros colgajos en la reconstrucción oromandibular:

- Gran longitud de hueso utilizable (hasta $25 \mathrm{~cm}$ ).

- Permite trabajar dos equipos quirúrgicos diferentes en la misma intervención.

- La gran vascularización perióstica permite la posibilidad de realizar múltiples osteotomías de remodelación. ${ }^{18}$

- Reinervación sensitiva de la isla cutánea. ${ }^{13}$

- Mínima morbilidad de la zona donante.

No obstante, el colgajo de peroné también presenta una serie de desventajas a saber:

- Se requieren múltiples osteotomías de remodelación con gran material de osteosíntesis.

- La altura del hueso obtenida es pobre, lo cual dificulta la posterior rehabilitación funcional con implantes osteointegrados. Moscoso, ${ }^{20}$ defiende que hay aproximadamente un $15 \%$ de varones y algo más en mujeres en los que no podemos colocar implantes por la escasa altura del peroné.

- La colocación de implantes se debe hacer de forma diferida debido a la gran cantidad de material de osteosíntesis que precisa la intervención. ${ }^{21}$

- Hueso con poca altura en defectos segmentarios, con diferencia de altura entre el colgajo y la mandíbula remanente y la desfavorable relación corona protésica-implante. Podemos solucionarlo bien mediante distracción vertical secundaria del peroné, ${ }^{22}$ o con el peroné en doble barra descrito por Jones. ${ }^{23}$

- La irrigación del componente cutáneo es muy inconsistente, debido a la gran cantidad de variantes anatómicas. Éste es el mayor problema de este colgajo. Para superar estos inconvenientes tenemos una serie de medidas como son:

- Centrar el parche en los dos tercios distales de la pierna donde hay más cantidad de perforantes de la arteria peronea.

- Tallar la paleta cutánea tan larga como se pueda para incorporar el mayor número de perforantes.

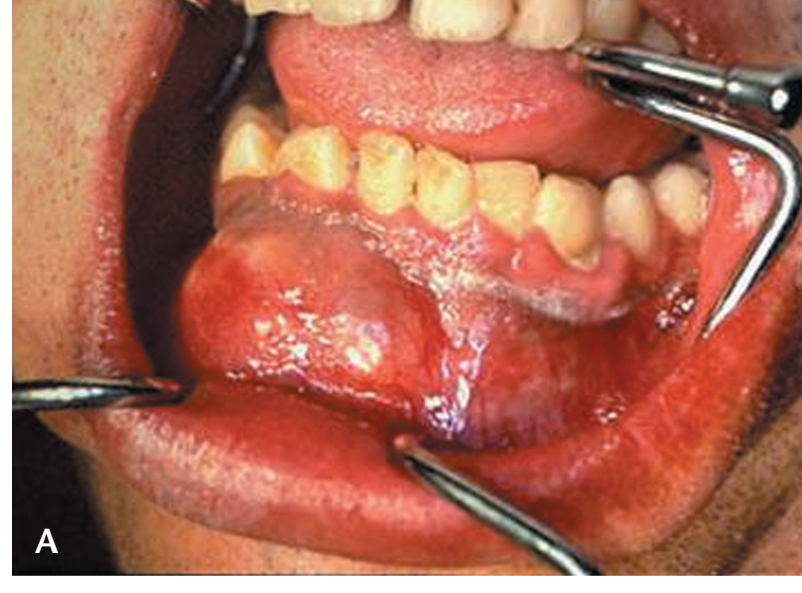

the prosthetic rehabilitation by means of osteointegrated implants, all patients except one were able to eat normal food. Proprioceptive sensitivity in approximately half of the cases was restored, and in many of the cases acceptable lingual mobility was achieved. All the osteointegrated implants were used except four, because there was no occlusion. As a result of the mandibular reconstruction carried out and the functional rehabilitation with osteointegrated implants, there have been considerable improvements for the patients with problems in the areas of mastication, swallowing, salivation and labial competence, and spectacular improvements have been achieved with regard to aesthetic facial harmony.

\section{Discussion}

Reconstructive surgery has experienced great advances over the last 20-30 years. Until recently mandibular reconstruction was based on pedicled bone flaps, reconstruction plates, bone grafts and alloplastic bands of bone particles. As a result of the development of microsurgical techniques and osteointegrated implants, integral treatment of oncological patients has improved considerably. ${ }^{17}$

Oromandibular rehabilitation is an arduous task that requires complex reconstruction that is individualized for each defect and adapted to the needs of the patient. Individualizing each case is fundamental, as is studying each patient in detail in order to select the right microsurgical flap for the reconstruction.

The microsurgical fibula flap has a series of advantages with regard to other flaps in oromandibular reconstruction:

- Usable bone of great length (up to $25 \mathrm{~cm}$ ).

- Two different surgical teams can work in the same intervention.

- The considerable periosteal vascularization that allows the possibility of carrying out multiple osteotomies for remodeling. ${ }^{18}$ 
- Abordar el parche cutáneo anteriormente hasta el septo e incluir una cuña muscular del sóleo y flexor largo del primer dedo para incorporar perforantes musculocutáneas.

- Aunque el estudio angiográfico es todavía un tema discutido, nosotros lo utilizamos de forma sistemática para demostrar, por un lado, que la arteria peronea está libre de enfermedad $y$, por otro para confirmar que no es la irrigación dominante de la pierna, en cuyo caso estaría contraindicado la utilización de este colgajo. ${ }^{24}$

- Requiere inmovilización postoperatoria de aproximadamente cinco a siete días, que se alargan hasta las tres semanas si se utiliza un injerto dermo-epidérmico (Fig. 6).

En la actualidad están bien establecidas las indicaciones para la utilización del colgajo libre de peroné:

- Reconstrucción mandibular asociada a importantes defectos de tejidos blandos intraorales.

- Reconstrucción de defectos mandibulares sinfisales, subtotales o totales que puedan llegar a superar los 14 $\mathrm{cm}$.

- Reconstrucciones de rama y cóndilo ya que permite deslizar el hueso hasta la cavidad glenoidea con una disección mínima y sin lesionar el nervio facial.

- Reconstrucción mandibular en edad pediátrica. Genden,25 establece que es el colgajo de elección en la edad pediátrica. En primer lugar, porque al no afectar a los centros de crecimiento distal y proximal, no altera el crecimiento de la pierna. $Y$ en segundo lugar, porque la neomandíbula formada crece al mismo ritmo que la mandíbula remanente. Okokawa, ${ }^{26}$ indica que en pacientes menores de ocho años se debe realizar una sinóstosis del tobillo para evitar la aparición del valgo.

La incorporación de la implantología osteointegrada en la rehabilitación oromandibular de pacientes oncológicos de cabeza y cueIlo, ha mejorado espectacularmente los resultados estéticos y funcionales. ${ }^{9}$

Branemark y Lindstrom ${ }^{14}$ utilizaron implantes en injertos óseos libres. Riediger, ${ }^{15}$ fue el primero en colocarlos en colgajos de cresta ilíaca y Navarro Vila y cols. ${ }^{7}$ en el colgajo osteomiocutáneo trapecial.

Para una perfecta rehabilitación funcional de los pacientes debemos resolver problemas que afectan a la masticación, deglución, salivación, y mejorar los resultados estéticos. Para conseguir todo esto es necesario un perfecto acoplamiento de las superficies den-
- Sensate reinervation of the skin island. ${ }^{13}$

- Minimum morbidity at the donor site. Nevertheless, the fibula flap also has a series of disadvantages, of note:

- Multiple osteotomies for remodeling are required together with large amounts of osteosynthesis material.

- The bone height obtained is poor, and posterior functional rehabilitation with the osteointegrated implants is hampered. Moscoso. ${ }^{20}$ claimed that in approximately $15 \%$ of males and somewhat more in females, implants cannot be placed because the fibula lacks height.

- The placement of implants has to be done in a second stage due to the surgery required for such a large amount of osteosynthesis material. 21

- Bone has little height for segmental defects, and there is a difference in height between the flap and the remaining mandible and an unfavorable crown-prosthetic-implant relationship. This can be solved successfully by means of secondary vertical distraction of either the fibula22 or by a "double-barrel" fibular graft as described by Jones. ${ }^{23}$

- The irrigation of the cutaneous component is very inconsistent, due to the large amount of anatomic variants. This is the main problem with this flap. In order to overcome these inconveniences we follow a set of measures that are:

- The patch should be centered on the two distal thirds of the leg where there are more perforating branches of the peroneal artery.

- The skin paddle should be as long as possible so that as many perforating vessels as possible are incorporated.

- The patch of skin should be approached anteriorly until the septum is reached and the muscular wedge formed by the soleus and long flexor muscle of the big toe should be included so that musculocutaneous per- 
tarias de ambos maxilares. Además, la buena vascularización de los colgajos microquirúrgicos favorece la incorporación de implantes para la recuperación de la función masticatoria de los pacientes. $27,28,30$

Como consecuencia de la reconstrucción mandibular y la radioterapia, se producen cambios en la musculatura orofacial, irregularidades óseas, pérdida del vestíbulo, alteraciones de la sensibilidad, xerostomía y atrofia de las mucosas que contraindica el uso de prótesis convencionales ya que éstos pueden producir irritación, ulceración y exposición ósea, ${ }^{29}$ que a veces terminan en una osteorradionecrosis

Gracias a la estabilidad protésica que proporcionan los implantes osteointegrados, no es necesario adelgazar el colgajo ni realizar vestibuloplastias secundarias en muchos casos, ${ }^{29}$ lo que facilita el procedimiento terapéutico.

Hay dos condiciones mínimas exigidas para la colocación de implantes osteointegrados:

- Altura ósea mínima de 10 mm. ${ }^{20}$

- Anchura ósea de aproximadamente 5,3 $\mathrm{mm}$ para colocar un implante de 3,3 $\mathrm{mm}$ de ancho y dejar $1 \mathrm{~mm}$ de hueso alveolar en cada cortical. ${ }^{31}$

Se ha demostrado que los colgajos óseos microvascularizados aceptan estadísticamente mejor los implantes que el hueso alveolar normal debido a su gran vascularización y, por ello, el efecto adverso de la radioterapia es mínimo. El colgajo de cresta ilíaca es el de mejor aporte vascular seguido por el peroné y la escápula. ${ }^{3}$

En el seguimiento realizado a nuestros 12 pacientes hemos comprobado que en 9 de ellos no ha existido ni si quiera la pérdida ósea perimplantaria que se admite como normal en los implantes sobre el hueso no trasplantado tras la carga protésica $(0,1 \mathrm{~mm} / \mathrm{año}) \cdot{ }^{32}$

La colocación de los implantes puede

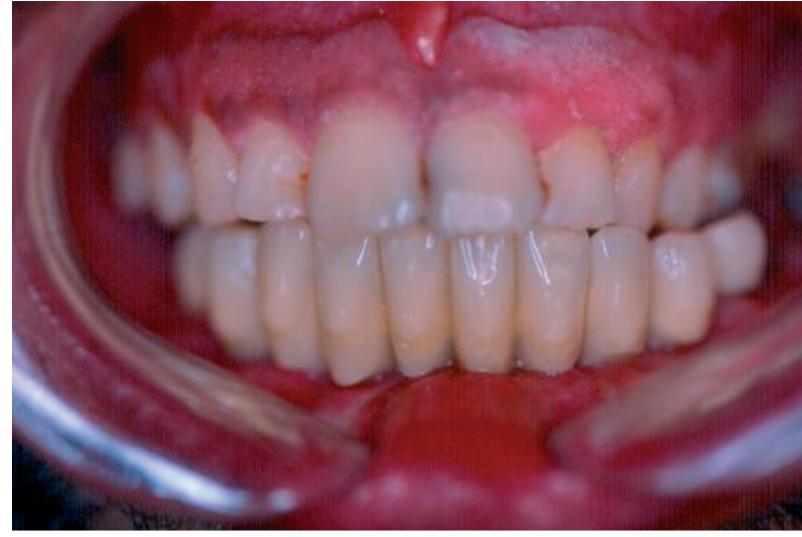

Figura 6. Rehabilitación protésica fija implantosoportada.

Figure 6. Rehabilitation with fixed implant-supported prosthesis.
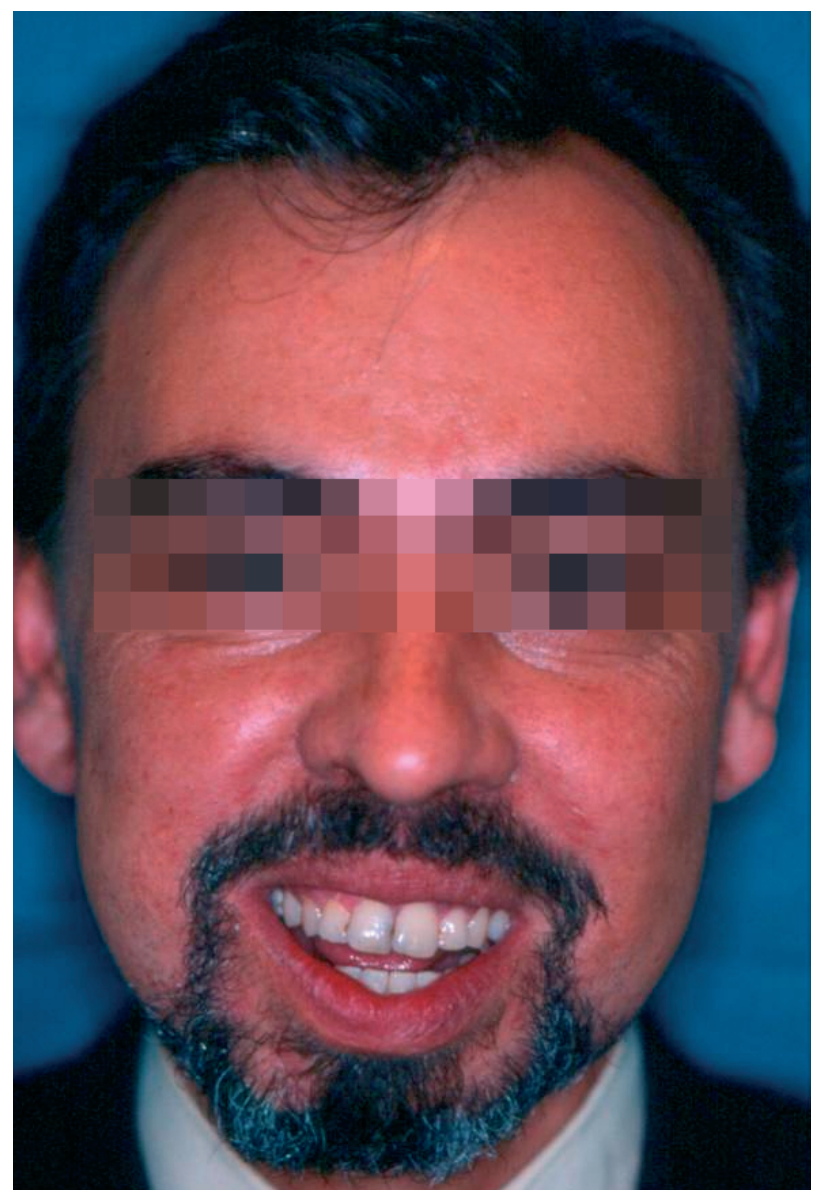

Figura 7. Aspecto final del paciente. Figure 7. Final appearance of patient. hacerse de forma inmediata (en el mismo acto quirúrgico). ${ }^{33}$ o diferida, una vez que han transcurrido un mínimo de 6 meses de la cirugía. Nuestro criterio, siempre que sea posible, es realizar la implantología de forma inmediata, ya que aporta una serie de ventajas:

- Rehabilitación funcional más rápida. ${ }^{9}$

- El acceso a la neomandíbula es más sencillo que en la colocación diferida. forating vessels are incorporated.

- Although angiographic studies are still the object of discussion, we used them systematically to demonstrate, on the one hand that the peroneal artery was free of disease, and on the other to confirm that it did not have dominant circulation in the leg, as in this case the use of this flap would be contraindicated. ${ }^{24}$

- The patient is required to remain immobile after the operation for five to seven days, and for up to three weeks if a dermoepidermal graft is used.

Currently the indications for using a fibula free flap are well established:

- Mandibular reconstruction in conjunction with considerable intraoral soft tissue defects.

- Reconstruction of symphyseal mandibular defects, either near total or total that may be over $14 \mathrm{~cm}$.

- Reconstruction of the branch and condyle as the bone can be moved to the glenoid cavity with minimal dissection and with no damage to the facial nerve.

- Mandibular reconstruction during childhood. Genden 25 established it as the flap of choice during childhood. Firstly, because it does not affect the distal and proximal growth centers, and growth of the leg is not affected. And secondly, because the new mandible grows at the same rhythm as the remaining mandible. Omokawa ${ }^{26}$ indicated that patients under the age of 8 should carryout a synostosis of the 
- Evitamos retracción de partes blandas y labio inferior.

- En los pacientes que van a recibir radioterapia postoperatoria se disminuye el periodo de tratamiento en 1 año.

No obstante, existe una importante controversia respecto al momento de realizar la implantología en pacientes que van a ser sometidos a radioterapia. Algunos, como Kroll, ${ }^{34}$ y Kuriloff, 32 recomiendan no utilizarlos de forma inmediata como precaución y diferirlos hasta aproximadamente doce meses. Sanger ${ }^{27}$ no los contraindica, al igual que nosotros. ${ }^{9} \mathrm{Al}$ contrario, pensamos que es un factor más para recomendar la colocación inmediata de los implantes. Por un lado, si entre la cirugía reconstructiva y el inicio de la radioterapia transcurren aproximadamente 4-6 semanas, tenemos otras 4-6 semanas adicionales hasta el inicio de los efectos adversos de la radioterapia en el hueso. Ésto proporciona un período ventana de unas 12 semanas. Tras este período en que todavía la radioterapia no ha afectado a la vascularización del hueso, las fases osteofílica y osteoconductiva de la osteointegración ya han tenido lugar. 17,35 Por otro, si se realiza la implantología de forma diferida, la neomandíbula presenta una vascularización mucho más pobre y la reabsorción ósea perimplante puede incrementarse, lo que representa una mayor dificultad y más posibilidades de complicaciones para la correcta rehabilitación del paciente.

En el colgajo de peroné, sin embargo, realizamos la implantología de forma diferida 6 meses después de la reconstrucción en pacientes no radiados y 12 meses después en aquéllos sometidos a radioterapia. Los motivos para esta decisión se basan en que la escasa altura del hueso peroneo, la realización de multiples osteotomías remodeladoras y la gran cantidad de material de osteosíntesis impiden, en la mayoría de los casos, la correcta colocación en número y posición de los implantes.

A la hora de decidir si los pacientes van a ser rehabilitados con una prótesis fija o removible debemos analizar una serie de factores:

- Número y posición de los implantes.

- Espacio oclusal.

- Arcada antagonista.

- Función de la A.T.M.

- Hipoestesias labiales y/o linguales.

- Higiene de la prótesis por parte del paciente.

La prótesis fija requiere un mayor número de implantes, el ajuste oclusal es más complejo y la higiene más difícil de mantener. De igual forma es un tratamiento más costoso pero proporciona una mayor satisfacción para el paciente en comparación con las prótesis removibles. Éstas precisan un menor número de implantes para su rehabilitación, el ajuste oclusal es más sencillo, el mantenimiento higiénico es más fácil y el coste, menor.

\section{Conclusiones}

Como conclusión final de este trabajo debemos decir que, a pesar de que la curación sigue siendo nuestro objetivo prioritario, el desarrollo de las técnicas microquirúrgicas y la implantología osteointegrada ha mejorado ostensiblemente el tratamiento integral de los pacientes oncológicos. Por tanto,queremos resaltar la posibilidad real que tenemos de ofrecer a los pacientes mandi- ankle in order to avoid the development of valgus deformity.

The incorporation of osteointegrated implantology in the oromandibular rehabilitation of oncological head and neck patients has improved aesthetic and functional results spectacularly. ${ }^{9}$

Branemark and Lindstrom ${ }^{14}$ used free bone grafts. Riediger ${ }^{15}$ was the first in placing them into iliac crest flaps and Navarro Vila et cols. ${ }^{7}$ into the trapezius osseomyocutaneous flap.

For perfect functional rehabilitation of patients we should resolve the problems that affect mastication, swallowing, salivation and the aesthetic results should be improved. In order to achieve this, it is necessary for the dental surfaces of the jaw fit together perfectly. In addition to this, proper vascularization of the microsurgical flaps favors the incorporation of the implants and the restoration of masticatory function for patients. 27,28,30

As a result of mandibular reconstruction and radiotherapy, changes take place in the orofacial muscles. There are bone irregularities, vestibular loss, changes in sensitivity, xerostomia and mucosal atrophy that contraindicates the use of conventional prostheses as irritation, ulceration and bone exposure may occur ${ }^{29}$ that can sometimes lead to osteoradionecrosis.

As a result of the prosthetic stability provided by the osteointegrated implants, refining the flap is not necessary, nor is carrying out secondary vestibuloplasties, ${ }^{29}$ which in many cases facilitates the therapeutic procedure.

There are two minimum conditions that are required for placing osteointegrated implants:

- minimum bone height of $10 \mathrm{~mm}^{20}$

- bone width of approximately $5.3 \mathrm{~mm}$ so that an implant with a width of $3.3 \mathrm{~mm}$ can be placed, while leaving 1 $\mathrm{mm}$ of alveolar bone in each cortical layer. ${ }^{31}$

It has been demonstrated statistically that microvascularized bone flaps are better at accepting implants than normal alveolar bone due to their greater vascularization and, as a result, the adverse effect of radiotherapy is minimal. The iliac crest flap has the best vascular supply followed by the fibula and the scapula. ${ }^{3}$

During the follow-up of our 12 patients, we were able to observe that in nine of the patients there was no periimplant bone loss, which is considered normal for implants into non-transplanted bone, after prosthetic loading (0.1 $\mathrm{mm} /$ year). ${ }^{32}$

Placing the implants can be carried out immediately (in the same surgical act) ${ }^{33}$ or this can be delayed until six months after the surgery. Our criteria is to carry out, whenever possible, the implantology immediately as this has a series of advantages:

- Faster functional rehabilitation. ${ }^{9}$

- Access to the new mandible is simpler than in delayed loading.

- Retraction of soft tissues and lower lip is avoided. 
bulectomizados y reconstruidos con colgajo de peroné, una rehabilitación dental con prótesis implantosoportadas y/o implantoretenidas, que van a mejorar su armonía facial y su calidad de vida. El índice de satisfacción con este tipo de tratamientos es muy alto dado que lo que demanda la mayoria de ellos tras la cirugía y la radioterapia, es la posibilidad de volver a tener dientes y comer con normalidad.

\section{Bibliografía}

1. Urken ML, Weinverg $\mathrm{H}$, Buchvinder $\mathrm{D}$, Moscoso JF, Lauson W. Microvascular free flaps in head and neck reconstruction. Report of 200 cases and review of complications. Arch Otolaryngol Head Neck Surg 1994;120:633-40.

2. Komisar A. Mandibular reconstruction: History and review of the literature. En: Komisar A. Mandibular Reconstruction. Ed Thieme, New York, 1997:1-9.

3. Cuesta GM. Implantes osteointegrados inmediatos en reconstrucción mandibular microvascular. Rev Esp Cirug Oral Maxilofac 1996;18,4:200-13.

4. Taylor GI, Miller DH, Ham FJ. The free vascularized bone graft. A clinical extension of microvascular techniques. Plast Reconstr Surg 1975;55:533-44.

5. Ueba Y, Fujikaua S. Vascularized fibula graft to neurofibromatosis of the ulna. A 9 years follow up. Orthop Surg Traumatol 1983;26:595-600.

6. Hidalgo D. Fibula free flap: a new method of mandibule reconstruction. Plast Reconst Surg 1989;84.

7. Navarro Vila C, Borja Morant A, Cuesta M, López de Atalaya FJ, Salmerón JI, Barrios JM. Aesthetic and functional reconstruction with the trapezious óseomyocutaneous flap and dental implants in oral cavity cancer patients. / Craniomaxilofac Surg 1996;24:322-9.

8. Navarro Vila C, López de Atalaya FJ, Cuesta Gil M, Verdaguer JJ. Nuestra experiencia reconstructiva en cáncer avanzado de cabeza y cuello. Rev Esp Cirug Oral Maxilof 1995;17:1-17.

9. Cuesta Gil M, Ochandiano S, Barrios JM, Navarro Vila C. Rehabilitación oral con implantes osteointegrados en pacientes oncológicos. Rev Esp Cirug Oral Maxilof 2001;23:171-82.

10. López de Atalaya FJ. Utilización de los colgajos microquirúrgicos en cirugía maxilofacial. Tesis Doctoral. Universidad Complutense. Madrid, 1996.

11. Hidalgo DA. Fibula free flap: a new method of mandibule reconstruction. Plast Reconst Surg 1989;84:71-79.

12. Wei FC, Chen HCh, Chuang ChCh, Noordhoff MS. Fibular Osteoseptocutaneus Flap: Anatomic Study and clinical Application. Plast reconst Surg 1986;78:191-9.

13. Hayden R, O'Leary M. A neurosensualy fibula flap. Anatomical description and clinical applications. 94 th Annual Meeting of the American. Laryngol Rhynolog Otolog Society Meeting. Hawaii 1991.

14. Branemark PI, Lindstrom J, Hallen O, Breine Ujeppson PH, Ohman A. Reconstruction of the defective mandible. Scand J Plast Reconstr Surg.1975;9:116-28.

15. Riediger, D. Restoration of masticatory function by microsurgically revascularized iliac crest bone grafts using endosseous implants. Plast Reconst Surg. 1988; $81: 861-6$

16. Urken ML, Buchbinder D, Weinberg H. Primary placement of osseointegrated implants in microvascular mandibular reconstruction. Otolaryngol Head Neck Surg 1989;101:56-73

17. Urken Ml, Weinberg H, Vickery C, Butchvinder D, Lauson W, Biller HG. Oromandibular reconstruction using microvascular composite free flaps. Arch Otolaryngol Head Neck Surg 1991;117:733-44.

18. Urken ML. Composite Free Flaps in oromandibular Reconstruction. Arch Otolaryngol Head Neck Surg 1991;117:724-32.
- For those patients that are to undergo postoperative radiotherapy, this is reduced by a year.

Nevertheless, there is considerable controversy with regard to when implants should be placed in patients that are going to undergo radiotherapy. Some authors such as Krol/34 and Kuriloff32 recommend that they are not placed immediately and for there to be a delay of approximately 12 months. Sanger ${ }^{27}$ like ourselves does not contraindicate this. ${ }^{9}$ On the contrary, we believe that this is another factor to recommend the immediate placement of the implants. On the one hand, if more than 4-6 weeks evolve between the reconstruction and the beginning of the radiotherapy, there are 4-6 additional weeks until the start of the adverse radiotherapy effects on the bone. This provides a window period of 12 weeks. During this period in which radiotherapy has not been affecting bone vascularization, the osteophylic and osteoconductive phases of osseointegration have taken place. 17,35 Furthermore, if delayed implant placement is carried out, the new mandible has poorer vascularization and peri-implant bone resorption can increase, which creates more difficulties and more possibilities of complications with regard to the correct rehabilitation of the patient.

However, with the fibula flap, delayed implantology was carried out six months after the reconstruction of non-irradiated patients, and 12 months later in patients that underwent radiotherapy. The motives behind this decision are based on the fibula bone lacking height and that multiple remodeling osteotomies are carried out. The large amount of osteosynthesis material will, in most cases, prevent the correct number of implants to be placed in the correct position.

When deciding if rehabilitation should include a fixed prosthesis or a removable prosthesis, a series of factors should be analyzed:

- Number and position of implants.

- Occlusal space.

- Antagonist arcade.

- TMJ function.

- Labial or lingual hypoesthesia.

- Patient's attitude to prosthetic hygiene.

The fixed prosthesis requires a larger number of implants, occlusal adjustment is more complex and maintaining hygiene is more difficult. Similarly, treatment is more costly, but it provides greater satisfaction for the patient in comparison with the removable prosthesis. This requires a lower number of implants for rehabilitation, occlusal adjustment is simpler, maintaining hygiene is easier and the cost is lower.

\section{Conclusions}

To conclude this paper we should say that, in spite of healing being our priority and objective, the development of microsurgical techniques and osteointegrated implantology has made ostensive improvements with regard to the integral treatment of oncological patients. Therefore, we would like to stress the real possibility that we have of offering 
19. Urken ML, Weinberg MD, Vickery C, Aviv JE, Buchbinder D, Lawswon W, Biller HF. The combined sensate radial forearm and iliac free flaps for reconstruction of significant glossectomy-mandibulectomy defects. Laryngoscope 1922;102: 543-58.

20. Moscoso JF, Keller J, Genden E, Weimberg H, Biller, HF; Buchbinder D, Urken ML. Vascularized bone flaps in oromandibular reconstruction. A comparative anatomic study of bone stock from various donor sites to asses suitability for enosseous dental implants. Arch Otolaryngol Head Neck Surg 1994;120:36-43.

21. Zlotolow IM, Huryn JM, Piro JD, Lenchewski E, Hidalgo DA. Osseointegrated implants and functional prosthetic rehabilitatio in microvascular fibula free flap reconstructed mandibles. Am / Surg 1992;164:677-81.

22. Marx RE, Ehler WJ, Peleg M. Mandibular and facial reconstruction. Bone 1996; 19:59s-82s.

23. Jones N, Swartz W, Mears D, Jupiter J, Grossman A. The "double- barrel" free vascularized fibular bone graft. Plast Reconst Surg 1988;81:378.

24. Hidalgo DA, Rekow A .A review of 60 consecutive fibula free flap mandible reconstructions. Plast Reconstr Surg 1995;96:585-96.

25. Genden E, Buchbinder D, Chaplin JM, Urken ML. Reconstruction of the pediatric maxillae and mandible. Arch Otolaryngol Head Neck Surg 2000;126:293-300.

26. Okokawa S, Tamai S, Takayura Y, Yajima H, Kawanishi K. A long term study of the donor ankle after vascularized fibula grafts in children. Microsurgery 1996;17:162-6.

27. Sanger JR, Head MD, Matloub HS, Yousift NJ, Larson DL. Enhancement of rehabilitation by use of implantable adjuncts with vasculariced bone grafts for mandible rconstruction. Am / Surg 1988; 156:243-7.

28. Urken ML, Buchbinder D, Weinberg H, Vickery C, Sheiner A, Parker R, Schaefer, J, Som P, Shapiro A, Lawson W, Biller HF. Functional evaluation following microvascular oromandibular reconstruction of the oral cancer patient: a comparative study of reconstructed and nonreconstructed patients. Laryngoscope 1991;101:935-50.

29. Lukash F, Sach S. Functional mandibular reconstruction: Prevention of oral invalid. Plast Reconst Surg 1992;90:105-11.

30. Urken ML, Moscoso JF, Lawson W, Biller HF. A systematic aproach to functional reconstruction of the oral cavity following partial and total glossectomy. Arch Otolaryngol Head Neck Surg 1994;120:589-601.

31. Frodel JL, Funk GF, Capper DT, Fridrich KL, Blumer JR, Haller JR, Hoffman HT. Osseointegrated implants: a comparative study of bne thickness in four vascularized bone flaps. Plast Reconstr Surg 1993;92:449-55.

32. Kuriloff Db, Sullivan MJ. Mandibular Reconstruction Using Vascularized Bone Grafts. Otolaryngol Clin North Am 1991;24:1391-417.

33. Urken ML, Weinberg H, Vickery C, Buchbinder D, Lawson W, Biller HF. The internal oblique -lliac crest free flap in composite defects of the oral cavity involving bone, skin and mucosa. Laryngoscope 1991;101:257-70.

34. Kroll SS, Schuterman MA, Reece GP. Immediate vascularized bone reconstruction of anterior mandibular.

35. Marx R, Morales MJ. The use of implants in the reconstruction of oral cancer patients. Dent Clin North Am 1998;42:177-201. mandibulectomized patients that have been reconstructed with a fibula flap, dental rehabilitation with an implant-supported prosthesis and/or implant-retained prosthesis that will improve facial harmony and quality of life. The satisfaction index with this type of treatment is very high, given that what most patients demand after surgery and radiotherapy, is the possibility of having teeth again and eating normally. 


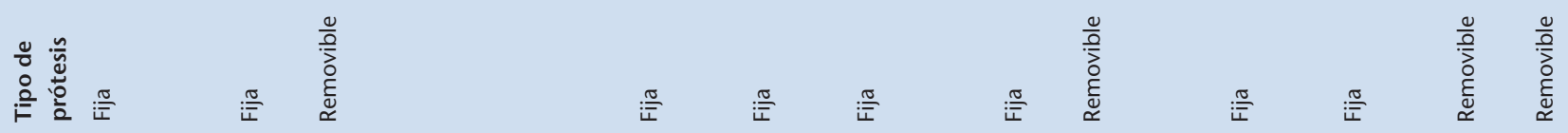

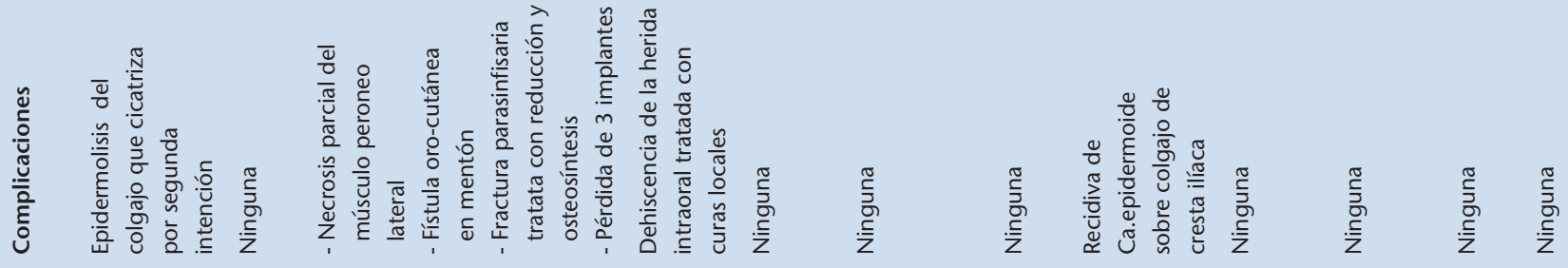

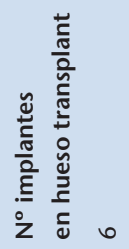

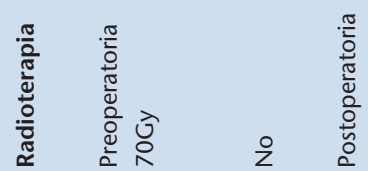

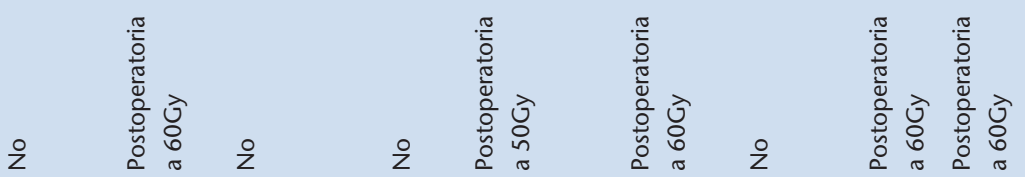

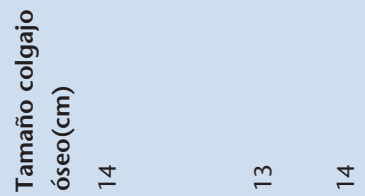

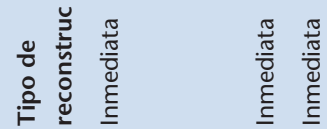

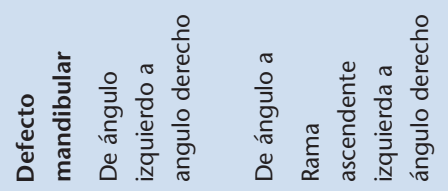

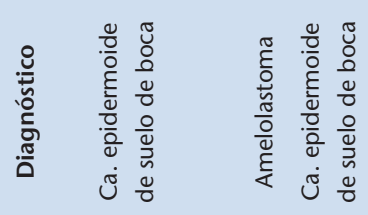

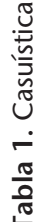

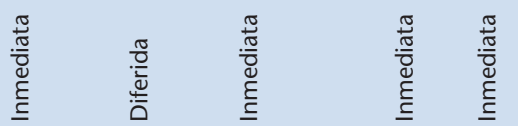

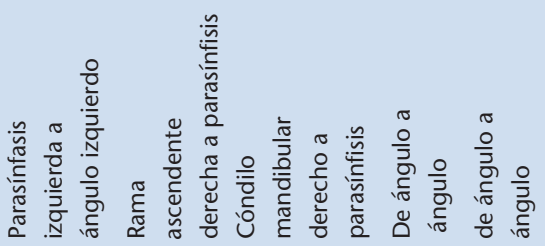

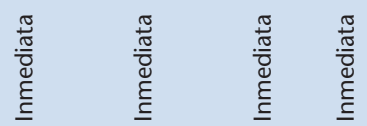

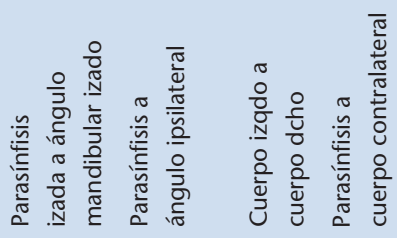

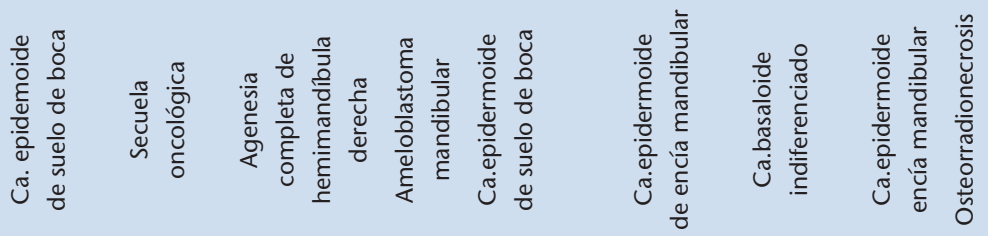

$\infty \quad$ ก

m $q$

8

ก

$5 \quad 5$ 


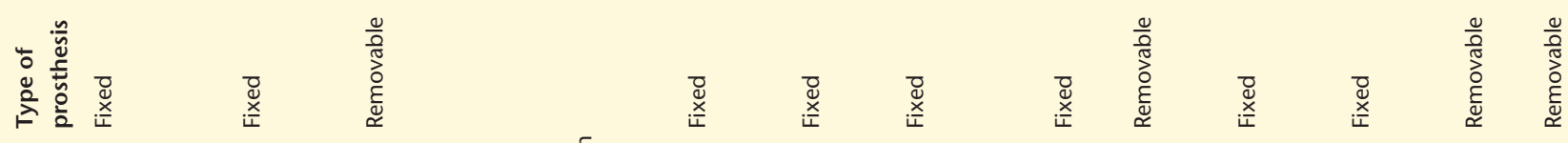

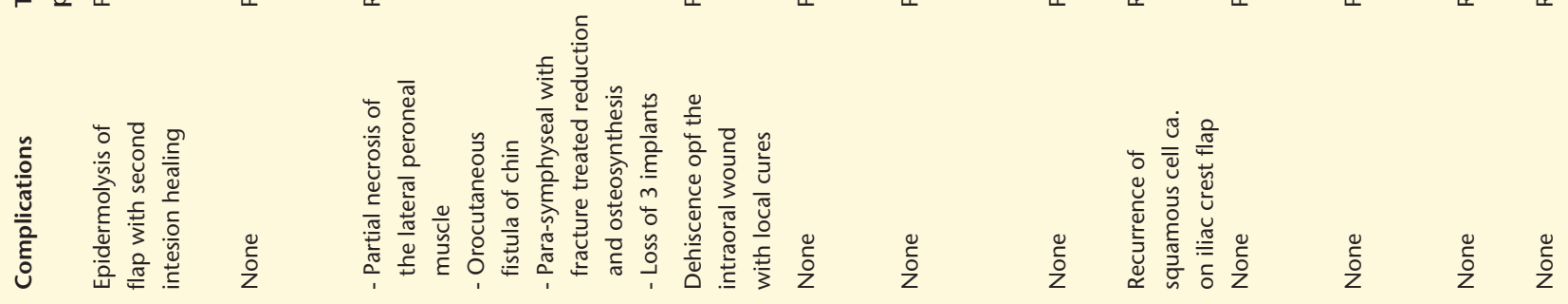

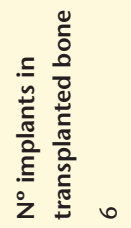

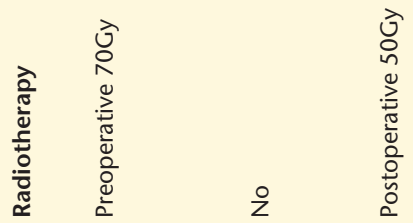

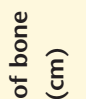

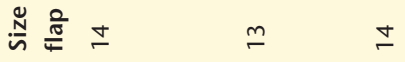

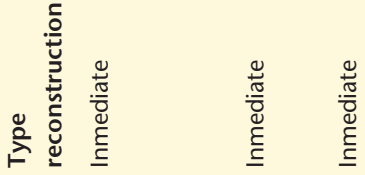

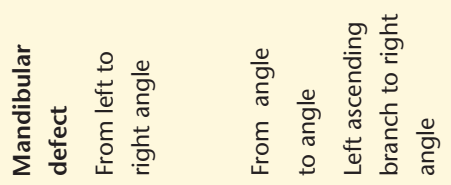

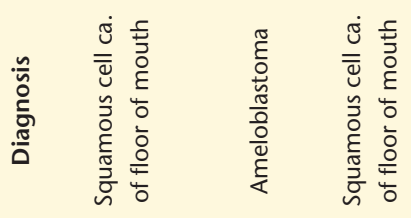

๗ $\Sigma \Sigma \Sigma \Sigma$

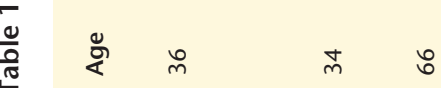

$|+||1|||||$

Whinhminh

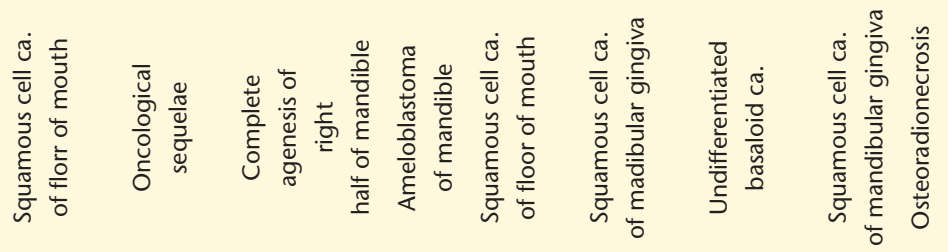

$\Sigma \quad \Sigma \quad \sim \quad \sim \quad \Sigma \quad \Sigma \quad \Sigma \quad \Sigma \Sigma$

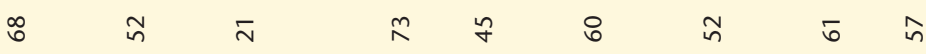

